\title{
Migration Challenges of the Current Stage of Globalization
}

\author{
Andrej Privara ${ }^{1, *}$ Eva Rievajova2 \\ ${ }^{1}$ University of Economics in Bratislava, Faculty of National Economy, Department of Social \\ Development and Labor, Dolnozemska cesta 1, 85235 Bratislava, Slovakia \\ ${ }^{2}$ University of Economics in Bratislava, Faculty of National Economy, Department of Social \\ Development and Labor, Dolnozemska cesta 1,852 35 Bratislava, Slovakia
}

\begin{abstract}
.
Research background: International labor migration is much less globalized than the other components of this process, mainly due to the various restrictions it continually encounters. Usually, the globalization of international migration results in complex migration systems. The migration challenges of the current stage of globalization include, among other things, changes in the categories of present migrants. The profile of migrants is becoming more and more diversified. It comprises women, minors, skilled people, entrepreneurs, and a low-skilled workforce or one who accepts a strong degree of disqualification.

Purpose of the article: The purpose of the paper is to identify processes of labor migration in the conditions of globalization, to analyze changes in the characteristics of migrants, as well as the paradox of complementarity between migration and globalization.

Methods: The authors used the methods of theoretical and empirical analysis. In addition to standard methods of theoretical analysis, they also used content analysis of text documents, mostly of an official nature. These were mainly national and European papers dealing with the issue of international labor migration in the context of globalization. Empirical research is based on the analysis of official data obtained from databases of international institutions (Eurostat, OECD, IOM, etc.).

Findings \& Value added: As a result of the analysis, the authors concluded about adequate European immigration policy and greater labor mobility would contribute to addressing labor market imbalances. At the end of the article, the authors also formulated specific measures to support mobility within the EU.
\end{abstract}

Keywords: globalization; international migration; labor market

JEL Classification: $J 21$; $J 64$

* Corresponding author: andrej.privara@euba.sk 


\section{Introduction}

International migration has become a significant challenge of the 21 st century. In the 1980 s, we entered the second great wave of migration of the present period, linked to 240 million international migrants. ${ }^{1}$

Nevertheless, the number of international migrants in relation to the world population appears to be relatively small from two points of view - compared to the period of massive migrations in the 19th century and the beginning of the 20th century and in comparison with other components of globalization such as international trade, foreign direct investment, financial capital, as well as technology flows. The total number of migrants in the world represents only $3 \%$ of the world's population and accounts for only $9 \%$ of the world's economically developed countries. In contrast, the volume of international trade measured by world exports represents about $30 \%$ of world GDP, and FDI accounts for more than $7.5 \%$ of domestic investment.

The paper aims to redefine the role of migration in the 21 st century, characterized by a strong interdependence between states due to the current stage of globalization. Many governments are trying to strengthen border controls at a time of economic liberalization and extreme mobility, while the work of several experts is demonstrating the benefits of migration from a human development perspective [1].

In this paper, we will first try to diagnose some processes caused by migration in the context of globalization. In this context, we will briefly analyze changes in the characteristics of migrants as well as the paradox of complementarity between migration and globalization. We will also draw attention to the existence of specific barriers to mobility within the EU. At the end of the article, we will formulate several proposals aimed at reducing these barriers.

\section{Methods}

In writing, the authors used standard methods of economic research: data collection, sorting, analysis and synthesis, system, and historical approach. Besides, they also used content analysis of text documents, mostly of an official nature. These were, on the one hand, national and European documents dealing with the issue of international migration in the context of globalization, but also scientific publications of an academic nature, registered primarily in the Web of Science Database.

Empirical research is based on the analysis of official data obtained from databases of international institutions (Eurostat, OECD, IOM, and ILO).

\section{Results}

\subsection{Globalization of international migration}

At the beginning of the 21st century, international migration became globalized. The number of migrants has tripled in the last 40 years. We can state that if 30 years ago only a few countries of the world were involved in international migration, today it marks almost all regions of the world - whether by the departure, arrival, or transit of migrants [2].

1 The first wave dates back to $1880-1930$. 
Several factors can explain this new phenomenon: the fall of the Berlin Wall allowed the mobility of a large number of inhabitants of the former socialist bloc; information disseminated through mass media, internet, and mobile phones have made it possible to create a more complex picture of the way of life and consumption in other parts of the world; the existence of migration networks has made it possible to exchange information whether it is family relationships or transnational entrepreneurs [3, 4]. After all, it is the absence of hope for a better and more dignified life in many developing countries that have been mobilizing factors since gaining political independence. In the present, most of these countries are affected by political, economic, and environmental crises, which does not give their people the belief that change will occur in the foreseeable future, which would mean an improvement in their life situation [5].

The fall of the Berlin Wall did not trigger the invasion of immigrants from the former socialist bloc, announced in 1990, but allowed millions of people to leave their country of origin and others to become circulating migrants.

An essential feature of international migration in the 21 st century is that entry into the host country is becoming increasingly difficult due to policies to control and combat illegal migration. It creates a situation that is inverse to the problem in the 19th century when it was difficult to leave the country of origin, but at the same time, it was easy to enter any other country. The explosion in asylum applications that we are currently monitoring is linked to the growing number of political crises and civil wars, which have led to an unprecedented increase in the number of refugees in recent years [6]. In this context, the following facts can be mentioned: since the end of the 1970s, 6 million people have left Afghanistan, and 4 million have left Iraq since the 1990s. Numerous crises in African countries, crises in the former Yugoslavia have contributed to the increase of migration flows [7].

Another essential feature of international migration in the 21 st century is that there are changes in the categories of migrants (for more details, see 3.2). These are a consequence of the evolution of the profile of migrants in time and space. Urbanization and the growth of education marked the end of the migrant's profile to date, a male illiterate from a rural environment. Such a migrant profile dominated especially in the 1960s. At present, almost half of the migrants are women. The presence of the middle class, wealthy entrepreneurs, and elites is also expanding.

\subsection{Changes in the characteristics of migrants}

There are currently two crucial characteristics of international migrant workers.

The first is the increasing flows of skilled migrants, mostly from economically backward countries [8]. In this context, it can be stated that although the overall rate of migration from economically backward countries is very low, the relationship between GDP per capita and the rate of skilled emigrants is inverse [9]. In general, the poorer the country, the higher the emigration rate. Examples include countries such as Haiti, where the rate of skilled emigration - i.e., the share of skilled emigrants in the number of skilled emigrants in the emigrant's country of origin - is $83 \%$, followed by Sierra Leone $(53 \%)$, Laos (37\%), Guyana (88\%), Vietnam (26\%), Uganda (34\%), Mexico (15\%). For China, India, and Brazil, as for most countries with an average level of GDP per capita, brain drain is only $5-6 \%$. It means that the poorer the country, the less the low-skilled workforce goes abroad, and the country of origin participates in globalization by offering the world labor market skilled workers [10].

The regions of Central America, sub-Saharan Africa, and South and East Asia are most affected by the brain drain. In these quite poor regions, the rate of emigration of skilled workers increased between 1980 and 2006. South Asia has seen a dramatic increase in the 
rate of emigration of skilled labor. In the North African region, this is a specific case, as the rate of emigration of skilled workers is higher than in other countries with an average level of GDP per capita [11].

The second important characteristic of international migrants in the current stage of globalization is the increasing share of women in the flows of international migrants. According to the IOM, the proportion of women in international migrant flows increased from $46.8 \%$ in 1960 to almost $50 \%$ in 2018. Many economists dealing with international migration have sought to examine the structure of migrants by gender. Their research clearly shows that women predominate in international labor migration (especially for highly skilled workers).

\subsection{Paradoxes of international migration in the current stage of globalization}

The first paradox, which contradicts generally accepted views, is that international migration has become the most dynamic tool for integrating the countries of the South into the world economy. It should be added that this is the case despite the massive restrictions that host countries are applying in this area [12].

For example, if we compare the flows of international migrants with the flows of foreign direct investment with short-term capital flows, with the transfer of technology and knowledge, or with flows of goods and services, we can say that it is the countries of the South that are feeling the effects of migration, especially in the form of remittances from migrants, which account for almost three times ODA. It is these countries that are the primary recipients of this income in both the short and long term [13]. For example, they account for 10 percent of the structure of GDP in Morocco, 12 percent in Mali, 18 percent in the Philippines, and 30 percent in El Salvador. Many developing countries make a living from these remittances. Simultaneously, the considerable polarization of FDI and foreign trade flows marginalizes them, and the volatility of short-term capital destabilizes them.

The second paradox, which contradicts the common notion, is that to reduce the incentives to emigrate, it is not enough to open the borders of foreign trade. This idea is inspired by the theory of international trade, according to which the free movement of goods is a substitute for the mobility of the factors of production, including the mobility of the labor force. From this point of view, labor should be used in migrants' countries of origin, and they should not need to emigrate.

However, as some studies prove, in reality, there is a complementary relationship between the country's opening to foreign trade, globalization as such and international migration $[14,15]$. The paradox of complementarity between migration and globalization could be formulated as follows: the more foreign trade and capital flow become globalized, the more migrants can reduce their mobility costs and thus leave their country of origin. In reality, therefore, opening up the economy to foreign trade first causes an increase in international migration because people have the opportunity to leave. It is also why the poorest countries, which have a small share in world trade, have the lowest migration rates.

In general, it is not enough to liberalize foreign trade for people not to leave their country.

\section{Discussions}

How to increase labor mobility and the effectiveness of migration policy at the EU level? 
Some European countries are already experiencing labor shortages, and many companies see this as a significant obstacle to growth, profit, and investment. Besides, Europe is facing an aging population, and it is widely acknowledged that immigration could mitigate its negative effects.

How to solve this problem? In principle, there are two ways to tackle it: the first is greater support for mobility within the EU, and the second is to make the European migration policy more effective.

\subsection{Stimulating mobility within the EU}

Mobility within the EU is relatively low, mainly due to linguistic and cultural differences, but also due to such a pre-order as recognizing the level of qualification achieved. At present, migration between EU countries affects 3.9\% of the European working-age population, representing around 11.8 million people. Just for comparison, in 2004, it reached a level of $1.6 \%$.

Language is proving to be the most crucial obstacle to mobility within the EU (European Commission, 2018). Erasmus + program for the years 2014-2020 with a budget of 14.7 billion euros (representing around $1.3 \%$ of the EU budget) can offer the opportunity to study abroad for less than $4 \%$ of young people living in Europe [ibid.].

Transnational corporation (TNC) strategies also have a significant impact on intra-EU mobility. TNCs can have a dual effect on migration flows. In case the TNCs from the EU15 are expanding their activities in Central Europe, they are sending some of their experts there, who are involved in the implantation of new companies or the restructuring of existing companies. They also participate in the transfer of modern technology. However, TNCs recruit local experts to work in their country of origin, but also to send them to work in the EU-15 and to integrate into the management structures of their highly qualified work teams. Thus, the development of TNC's activities in Central Europe is reflected in significant flows of skilled workers in both directions.

TNC strategies in Central European countries are also among the means of inhibiting brain drain from these countries and supporting return migration. The point is that the massive implantation of TNCs in Central Europe is associated with the fact that they can offer career and wage opportunities comparable to those in Western Europe. In other words, the massive implantation of TNCs in Central Europe has the effect (in addition to the transfer of modern technology) of creating jobs for top professionals as well as raising their wages to a level sufficient to remain in the country of origin and can even stimulate highly qualified workers to return migration.

The low rate of migration within the EU is also justified by the persistent differences between social protection systems in different countries. To increase incentives for mobility, it is necessary to introduce more harmonized social security systems.

The Electronic Exchange of Social Security Information (EESSI), a digital platform connecting EU social security institutions at the national, regional, and local level, launched in 2019, provides faster, easier, and more secure access to social security information across the EU. In this way, citizens living and working in several Member States can calculate their social security benefits more quickly and efficiently.

\subsection{Making European migration policy more effective}

The EU could do better in the global competition for talent (Figure 1). As shown in Figure 1, the EU has the lowest level of foreign-born residents in relation to the total population among other host countries. 


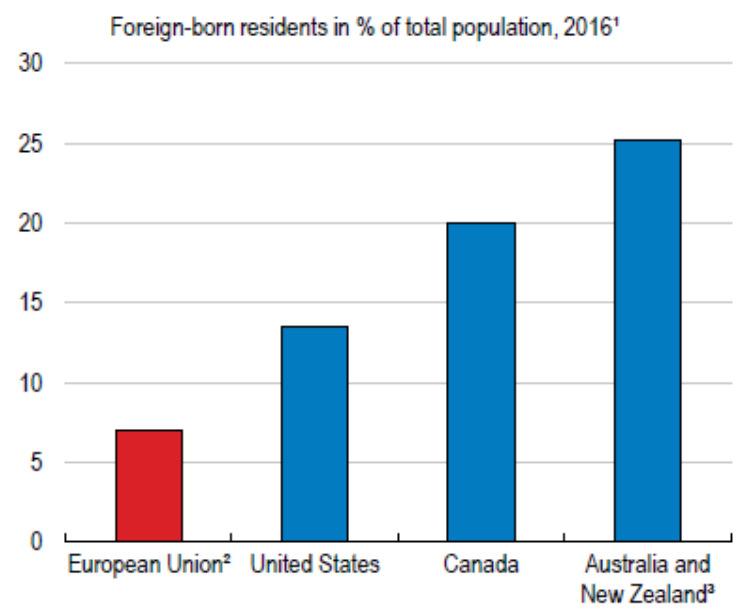

Fig. 1. Stock of foreign-born population $[16,17]$

1. 2015 for the Union States, 2014 for Australia-New Zealand and 2013 for Canada.

2. Mid year estimate, excluding intra-EU mobility.

3. Excluding bilateral mobility between Australia and New Zealand themselves.

Source: Eurostat (2018) «Population Statistics»

StatLink 2 http://dx.doi.org/10.1787/888933748059

The fundamental problem is that labor market regulation and immigration are different in each Member State. The European Blue Card, a system that allows highly qualified thirdcountry nationals to live and work in any European country (except Denmark, Ireland, and the United Kingdom), has been set up to attract skilled migrants by providing them with a level playing field and a whole set of rights, to settle and work in the EU, in particular simplified movement within the EU and easier access to long-term resident status. However, because of some factors, such as the administration of issuance of the European Blue Card, it has proved insufficient measure, as evidenced by the low number of cards issued (Figure 2). We believe that legislation should be simplified if interest in the European Blue Card is to increase.

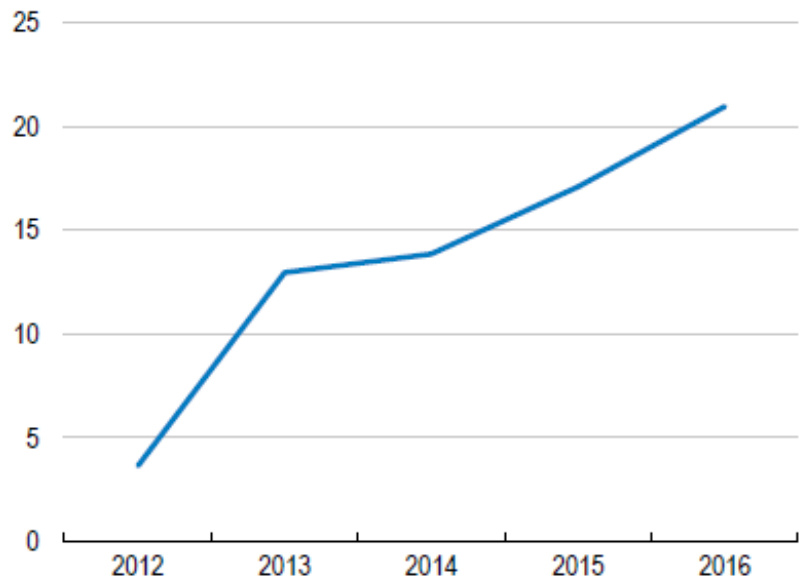

Fig. 2. Number of Blue Cards granted in the EU (Thussends), [16, 17]

Source: Eurostat Database, OECD (2018) «International Migration Statistics》 Statlink 2 http://dx.doi.org/10.1787/888933748059 


\section{Conclusions}

At the current stage of globalization, European labor markets face difficult (but not insurmountable) challenges. These are associated with the scarcity of required qualification of manpower - especially the highly qualified (especially highly qualified) workforce.

We see a solution to increase labor mobility within the EU (among which the TNC strategy has an irreplaceable role to play) and more effective migration policy at the EU level. In this context, it should be added, in addition to the above, that it is now essential for refugees to integrate rapidly into the society of the host countries. It is in the interest of the host countries to raise their standard of living and to improve their prospects of employment, as well as to at least partially address the aging of the European population and to increase the confidence of host citizens towards immigrants. Europe has registered the largest number of asylum seekers since World War II, which many Europeans are concerned about, as Eurobarometer statistics show. A coordinated and comprehensive strategy for the effective integration of asylum seekers is needed at the EU level. The best way to achieve this is to give them access to employment quickly. Promoting accelerated access to the labor market, increasing jobs in integration programs and language courses (including vocational language training), accurately assessing the level of skills of immigrants, and distributing asylum seekers to regions where the labor market situation in the host country is more favorable are measures to stimulate not only raising the living standards of immigrants, but also inclusive growth in the host country.

Contribution is an output of the VEGA research project no. 1/0037/20: "New challenges and solutions for employment growth in changing socio-economic conditions".

\section{References:}

1. PNUD (2009). Lever les barrières. Human mobility and development. In the World Report on Human Development.

2. Tsapenko, I. P., \& Sautkina, V. A. (2018). Global migrations and health economics. Terra Economicus, 16(1), 84-100.

3. Manthei, G., \& Raffelhüschen, B. (2018). Migration and Long-Term Fiscal Sustainability in Welfare Europe: A Case Study. FinanzArchiv: Public Finance Analysis, 74(4), 446-461.

4. Canelon Silva, A. R., \& Almansa Martinez, A. (2018). Migration: challenges and opportunities from the perspective of Sustainable Development Goals (SDGs). RETOS. Revista de Ciencias de la Administración y Economía, 8(16), 109120.

5. Drakokhrust, T., Prodan, I., \& Tkach, U. (2019). Migration challenges: trends and implications for Ukraine and countries of eastern Europe. Baltic Journal of Economic Studies, 5(2), 30-37.

6. Hatton, T. J. (2020). Asylum Migration to the Developed World: Persecution, Incentives, and Policy. Journal of Economic Perspectives, 34(1), 75-93.

7. Gignarta, T. S., Guan, Z., \& Borojo, D. G. (2020). The Impacts of Economic Freedom and Institutional Quality on Migration from African Countries. South African Journal of Economics, 88(3), 242-266.

8. Kasnauskiene, G., \& Palubinskaite, J. (2020). Impact of High-Skilled Migration to the UK on the Source Countries (EU8) Economies. Organizations and Markets in Emerging Economies, 11(1), 55-68. 
9. Privara, A., Rievajova, E., \& Barbulescu, A. (2020). Attracting High Skilled Individuals in the EU: The Finnish Experience. Migration Letters, 17(2), 369-377.

10. Sirkeci, I., Cohen, J. H., \& Privara, A. (2017). Towards a Migration Letters Index: the most influential works and authors in Migration Studies. Migration Letters, 14(3), 397-424.

11. Esposito, P., Collignon, S., \& Scicchitano, S. (2019). Immigration and unemployment in Europe: does the core-periphery dualism matter? Economic Modelling, 84, 249258.

12. Sirkeci, I., Acik, N., Saunders, B., \& Privara, A. (2018). Barriers for highly qualified A8 immigrants in the UK labour market. Work, employment and society, 32(5), 906924.

13. Privarova, M., Privara, A., \& Pitukhina, M. (2018). Remittances and Their Role in Development. Advanced Science Letters, 24(9), 6326-6328.)

14. Facchini, G., Liu, M. Y., Mayda, A. M., \& Zhou, M. (2019). China's "Great Migration": The impact of the reduction in trade policy uncertainty. Journal of International Economics, 120, 126-144.

15. Acharyya, R., Beladi, H., \& Kar, S. (2019). Trade, migration costs and asymmetric migration patterns. The World Economy, 42(9), 2629-2648.

16. European Commission (2018). Action plan: Financing the last step. Communication from the Commission to the European Parliament, the European Council, the European Economic and Social Committee and the Committee of the Regions. Brussels.

17. OECD (2017). Perspectives économiques de l'OCDE. OECD iLibrary, 2017(2), OECD Editions, Paris, http://dx.doi.org/10.1787/eco_outlook-v2017-2-fr. 